\title{
Properties of Biochar Prepared from Acacia Wood and Coconut Shell for Soil Amendment
}

\author{
Pinitpon Pituya ${ }^{1,4}$, Thavivongse Sriburi ${ }^{2 *}$, and Saowanee Wijitkosum ${ }^{3}$ \\ 1 Inter-department of Environmental Science, Graduate School, Chulalongkorn University, Bangkok \\ 10330, Thailand \\ 2 Chula Unisearch Center, Chulalongkorn University, Bangkok 10330, Thailand \\ 3 Environmental Research Institute, Chulalongkorn University, Bangkok 10330, Thailand \\ 4 Huaysai Royal Development Study Center, Petchaburi Province, 76120, Thailand \\ *E-mail: thavivongse.s@chula.ac.th (Corresponding author)
}

\begin{abstract}
The biochar produced from the agricultural wastes was aimed to amend the extreme degraded soil. The properties of biochar prepared from Acacia wood and coconut shell were investigated by different pyrolysis conditions in order to identify the suitable initial biomass of biochar applied for sandy soil amendment. The slow pyrolysis was applied for preparing biochar under different conditions. The temperature was varied from 300,400 and $500{ }^{\circ} \mathrm{C}$ meanwhile the pyrolysis times were varied to 1,2 and 3 hours. The parameters indicating biochar property are SA, APD, elemental contents of $\mathrm{C}, \mathrm{H}, \mathrm{O}$ and $\mathrm{N}$, $\mathrm{pH}, \mathrm{CEC}$, and WHC. The properties of Acacia biochar and coconut shell biochar were compared using paired T-test at 95\% confident interval to analyze the significant difference. The results indicated that the types of the initial biomass and the pyrolysis conditions have an impact on the properties of biochar for both physical and chemical. The suitable temperature was $500{ }^{\circ} \mathrm{C}$ for 2 hours. The different types of biomass are significantly effect on the $\mathrm{SA}, \mathrm{C}$ and $\mathrm{O}$ contents, $\mathrm{pH}, \mathrm{CEC}$ and $\mathrm{WHC}$ of the prepared biochar $(\mathrm{P}<0.05)$. Properties of Acacia wood biochar indicate that it is more suitable than coconut shell biochar to be applied as sandy soil amendment due to its higher SA, higher CEC, and neutral pH. Meanwhile, coconut shell biochar also can be applied for the typical soil appropriate and increase crop yield.
\end{abstract}

Keywords: Properties of biochar, soil amendment, sandy soil, Acacia wood, coconut shell.

ENGINEERING JOURNAL Volume 21 Issue 3

Received 30 May 2016

Accepted 6 December 2016

Published 15 June 2017

Online at http://www.engj.org/

DOI:10.4186/ej.2017.21.3.63 


\section{Introduction}

Agricultural waste in developing countries includes all organic and inorganic wastes produced from agricultural activities [1] such as harvest waste, residues from farming and other organic by-products. Challenges of agricultural waste management in those developing countries including Thailand rely on available knowledge and technologies which is very specific to local physical, biological and social environment. However, waste reuse and recycle are prioritized and referable [2] rather than energy recovery use. In a developed country such as the United States, organic wastes for a sustainable agriculture was aimed for sustaining the soil productivity [3] because of the benefits of organic wastes on soil physical properties and improvement of soil productivity. In Thailand, the biomass waste produced from agricultural area 122.2 million Rais (or 19.6 million hectares) or $38.2 \%$ of total country area. These organic wastes from the agricultural activities were studied in various utilization routes including fertilizer application, fermentation, pollution control, animal feed, fuel, and pyrolysis. The utilizations were mostly for soil fertility improvement such as compost and liquid bio-extract fertilizer [4,5] and crop yield enhancement $[6,7]$. The impacts of recycling wastes also aim for soil water and soluble nutrient retention [8]. Biological charcoal or biochar is a product of $350-500{ }^{\circ} \mathrm{C}$ pyrolysis of biomass waste $[9,10]$ to achieve the degradation resistance $[11,12]$, and is amended in degraded soil for soil improvement and agricultural production. For the improvement of degraded soil, the biochar amended soil showed significant nutrient uptake in wheat [13], and other economic plants in many countries [14-18]. The pyrolysis biomass contains functional sites which change chemical and physical properties in biochar amended soil [19-21] such as change nutrient availability, cation exchange capacity (CEC), $\mathrm{pH}$, soil strength, and water holding capacity [22]. The biochar application in soil also showed as a means of carbon sequestration and maintain or improve soil ecological functions [23] by increased total carbon [24], total nitrogen, $\mathrm{pH}$, available $\mathrm{P}$, and exchangeable cations (e.g. $\mathrm{Ca}, \mathrm{Mg}, \mathrm{Na}$, and $\mathrm{K}$ ) in soil ecosystem [25]. These properties of the initial biomaterial and the pyrolysis conditions are the important factors affecting the biochar properties [26] which can be used for determining the final application of the biochar and its effect in soil [27]. For example, larger pores in the biochar are the result of the vascular structure of the original biomass [22]. Increased inorganic elements of the initial biomass result in decreased carbon content of the resulting biochar [28] while high carbon material at $300-700{ }^{\circ} \mathrm{C}$ showed better biochar amended soil properties depending on the carbon content in the initial biomass such as Acacia wood and coconut shell. However, the enhancement of crop productions also depend on frequency and concentration of biochar application in different soil types [13, 16, 17, 29-32]. Hence, the application of biochar for sustainable agricultural management still need continuous research to find out the best management practices under different soil regimes. The sandy soil at the Huay Sai Royal Development Study Center located in Cha-am District, in Petchaburi Province, Thailand retarded green area development. Crops growing in the sandy soil need soil moisture to deliver the dissolved nutrients to plant roots. Therefore, the study was aimed to improve the sandy soil properties by application of biochar. The properties of biochar prepared from different biomass waste: Acacia wood and coconut shell were observed and analyzed in order to identify the suitable biochar application rate for sandy soil improvement.

\section{Methodology}

\subsection{Raw Material and Biochars Preparation}

The raw materials for biochars preparation were made from agricultural waste, Acacia wood (Lencocephala glauca Benth.) and coconut shells(Cocos nucifera Linn. Palmae). The $300 \mathrm{~g}$ of $2 \times 2 \times 2 \mathrm{~cm}^{3}$ bio-raw materials were air dried in open air for 2 weeks and placed in a clay pot with a cover lid before carbonization in the Nabertherm Lab Furnace (Models Muffle furnace LT 5/12, 30 to. $3000{ }^{\circ} \mathrm{C}$, Germany) at Environmental Science Department, Faculty of Science, Chulalongkorn University. The pyrolysis conditions [14, 15] of two biomass samples were set at slow pyrolysis heating steps of $10{ }^{\circ} \mathrm{C}$ per minute, following Biochar standard of the International Biochar Institative [33]. until reaching 300, 400 and $-500^{\circ} \mathrm{C}$ of setting temperatures varied with 1,2, and 3 hours respectively ( 2 samples $\times 3$ temperatures $\times 3$ time periods $\times 3$ replications). After carbonization, the biochar samples were left to cool in the furnace until room temperature and kept in a desiccator before the laboratory study. The three sample replications were composite sampled; therefore, nine composite samples were prepared for biochar property analysis. 


\subsection{Analysis of Properties of Biochar}

The prepared biochar particles of all composite samples were sampled analyzed by using the scanning electron microscope (SEM). The biochar properties which related to its functions for soil condition improvement were determined for the surface area (SA) and average pore diameter (APD) by adopting the Brunauer-Emmett-Teller (BET) multipoint method (Autosorb- I Series Quantachrome Instruments, USA), $\mathrm{pH}$ of biochar and water ratio 1:5 by $\mathrm{pH}$ meter (Mettler Toledo, USA), elements (C, H, N and O) measured by using atomic analyzer (2400 CHN Elemental Analyzer, Perkin Elmer, USA) and CEC at pH 7 with ammonium acetate [34]. All data represent composite sample conditions and present as means values. The significant differences of furnace temperature that effects band were calculated with an alpha level of 0.05 by using Minitab version17 (Minitab Inc.) and to find the 2-D contour line of biochar properties. Tukey's range test was used to indicate significance among ordered means [35].

\section{Results and Discussion}

The biochar amendation in low fertile soil may affect soil and crop relation depending on site specificity and biochar properties. There are many parameters involving the properties of biochar in soil improvement such as initial biomass from different plants and conditions of furnace [36-38].

\subsection{Properties of Biochar}

The two plants, Acacia wood (AC) and coconut shell (CS) were prepared for the 300,400 , and $500 \mathrm{C}$ varied with 1, 2 and 3 hours in the furnace. The study showed that both temperature and timing of carbonization expressing some effects to biochar properties for soil chemical and physical improvement including surface area of substrate particles, porosity, available water in soil pores and soil nutrient cation exchange capacity (Table 1). The SEM images present different morphology of biochar affected by the different initial biomass materials of Acacia wood and coconut shell, pyrolyzed at different temperatures in 2 hours (Fig. 1).

The physical and chemical properties of biochar prepared from Acacia wood (AC) and coconut shell (CS) were illustrated in Figs. 2 to 10. For the physical properties, the surface area (SA) of biochar increased at the higher pyrolysis temperature. The highest SA of biochar prepared from both raw materials was increase significantly at $500^{\circ} \mathrm{C}$ with 2 hours pyrolysis time; although it slightly increased at 3 hours of pyrolysis period (Fig. 2). On the contrary, the average pore diameter (APD) of biochar decreased at the higher pyrolysis temperature (Fig. 3). The obtained APD depend on types of initial biomass and condition of carbonation. The highest APD of biochar prepared from Acacia wood was produced at $300^{\circ} \mathrm{C}$ with 1 hour pyrolysis time while the biochar prepared from coconut shell was at $300^{\circ} \mathrm{C}$ for 2 hours.

The increase of surface area which directly increase the soil nutrient absorption [37, 38]; however, the application of biochar depend on certain parameter for soil condition improvement. It can be limited by the soil $\mathrm{pH}$ changed caused by biochar $\mathrm{pH}$ property (Fig. 4). The $\mathrm{pH}$ of biochar which was prepared from Acacia wood trends to be weak acidic to weak basic while of biochar prepared from coconut shell trends to be more basic. The carbon content of biochar increased while hydrogen content and oxygen contents decreased with increasing temperature (Figs. 5, 6, and 7) whereas the nitrogen values of biochar prepared from all conditions was stable and very low (Fig. 8). This indicates an increasing degree of carbonization [26].

The chemical property of biochar was reported in the terms of CEC that influence the absorption capacity of soil nutrient feeding. The CEC of biochar influenced by type of initial biomass by showing that the maximum 41.30 to $127.45 \mathrm{cmol} / \mathrm{kg}$ of CEC found from Acacia wood biochar was higher the maximum 13.67 to $61.23 \mathrm{cmol} / \mathrm{kg}$ of $\mathrm{CEC}$ at $500{ }^{\circ} \mathrm{C}$ for 3 hours of biochar prepared from coconut shell (Fig. 9). Moreover, the CEC values of Acacia wood biochar were significantly higher than those of coconut shell biochar at $95 \%$ of confidential of interval $(\mathrm{P}<0.05)$ by using Paired T-test. The water holding capacity (WHC) was different by difference of the initial biomass types. The WHC of Acacia was highest at 303.30 to $426.20 \%$ of biochar which was prepared at $300{ }^{\circ} \mathrm{C}$ for 1 hour whereas the maximum WHC of coconut shell biochar prepared at $300{ }^{\circ} \mathrm{C}$ for 1 hour was only 35.30 to $75.3 \%$ (Fig. 10). 
Table 1. Properties of biochar prepared from Acacia wood (AC) and coconut shell (CS) under nine different pyrolysis conditions (Three (3) varied temperatures $x$ three (3) varied time periods of incineration).

\begin{tabular}{|c|c|c|c|c|c|c|c|c|c|c|c|}
\hline & \multicolumn{3}{|c|}{ Pyrolysis Conditions } & \multicolumn{8}{|c|}{ Physical and Chemical Properties of Biochar } \\
\hline & $\begin{array}{c}\text { Temperature } \\
\left({ }^{\circ} \mathbf{C}\right)\end{array}$ & $\begin{array}{l}\text { Time } \\
\text { (hour) }\end{array}$ & $\begin{array}{c}\text { SA } \\
\left(\mathrm{m}^{2} / \mathrm{g}\right)\end{array}$ & $\begin{array}{c}\text { APD } \\
(\AA ̊)\end{array}$ & $\% \mathrm{C}$ & $\% \mathrm{H}$ & $\% \mathbf{N}$ & $\% \mathrm{O}$ & $\mathrm{pH}$ & $\begin{array}{c}\text { CEC } \\
(\mathrm{cmol} / \mathrm{kg})\end{array}$ & $\begin{array}{c}\text { WHC } \\
\%\end{array}$ \\
\hline \multirow[t]{9}{*}{$\mathrm{AC}$} & 300 & 1 & 2.14 & 71.87 & 68.85 & 3.44 & 0.02 & 27.66 & 6.0 & 69.86 & 426.20 \\
\hline & 300 & 2 & 4.09 & 57.78 & 66.91 & 3.41 & 0.02 & 29.55 & 5.5 & 106.30 & 344.40 \\
\hline & 300 & 3 & 6.09 & 59.73 & 67.56 & 3.52 & 0.02 & 28.85 & 5.0 & 127.45 & 355.10 \\
\hline & 400 & 1 & 4.56 & 63.8 & 68.21 & 3.62 & 0.02 & 28.07 & 5.6 & 87.80 & 352.60 \\
\hline & 400 & 2 & 108.89 & 25.55 & 66.98 & 4.30 & 0.22 & 28.46 & 6.8 & 102.60 & 303.30 \\
\hline & 400 & 3 & 100.56 & 26.85 & 68.68 & 3.13 & 0.06 & 28.09 & 6.2 & 96.81 & 380.20 \\
\hline & 500 & 1 & 330.63 & 22.87 & 72.98 & 2.92 & 0.10 & 23.99 & 7.9 & 41.30 & 313.80 \\
\hline & 500 & 2 & 370.37 & 22.41 & 70.74 & 2.98 & 0.10 & 26.07 & 7.8 & 69.26 & 345.60 \\
\hline & 500 & 3 & 376.51 & 23.07 & 73.26 & 2.91 & 0.08 & 23.64 & 7.7 & 64.40 & 365.70 \\
\hline \multirow[t]{9}{*}{$\mathrm{CS}$} & 300 & 1 & 1.03 & 60.60 & 53.47 & 3.70 & 0.10 & 42.57 & 6.4 & 34.76 & 69.78 \\
\hline & 300 & 2 & 1.03 & 95.26 & 48.32 & 3.93 & 0.01 & 47.56 & 6.5 & 26.25 & 70.03 \\
\hline & 300 & 3 & 0.95 & 80.07 & 43.46 & 3.62 & 0.01 & 52.76 & 6.9 & 55.09 & 75.30 \\
\hline & 400 & 1 & 4.01 & 48.21 & 31.84 & 3.08 & 0.02 & 64.87 & 7.2 & 19.92 & 56.65 \\
\hline & 400 & 2 & 8.76 & 40.57 & 43.08 & 3.17 & 0.01 & 53.62 & 8.8 & 13.67 & 52.62 \\
\hline & 400 & 3 & 11.32 & 40.30 & 54.28 & 3.16 & 0.01 & 42.54 & 9.1 & 26.34 & 49.15 \\
\hline & 500 & 1 & 199.38 & 27.07 & 65.48 & 3.15 & 0.01 & 31.35 & 9.3 & 24.95 & 54.13 \\
\hline & 500 & 2 & 347.96 & 22.06 & 64.77 & 2.93 & 0.01 & 32.29 & 8.9 & 14.74 & 38.90 \\
\hline & 500 & 3 & 351.95 & 22.20 & 64.06 & 2.70 & 0.01 & 33.20 & 8.9 & 61.23 & 35.30 \\
\hline
\end{tabular}

Note: $*$ The results represent an average instrumental measurement of composite sample.
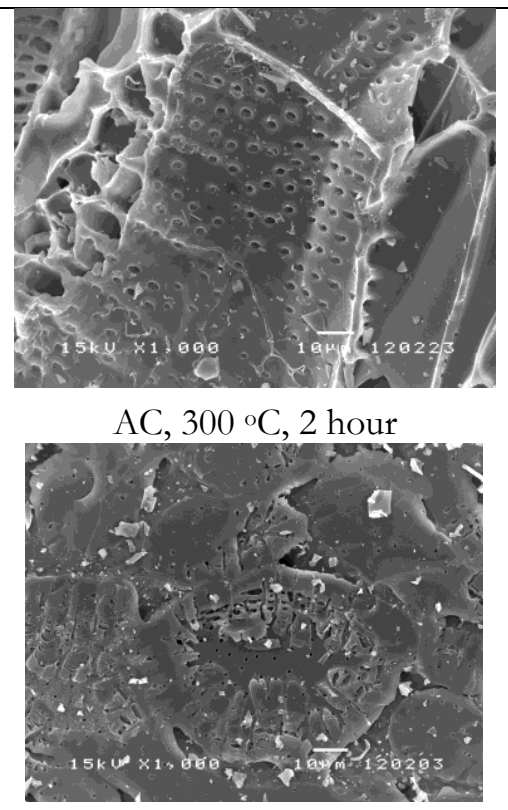

$\mathrm{CS}, 300^{\circ} \mathrm{C}, 2$ hour

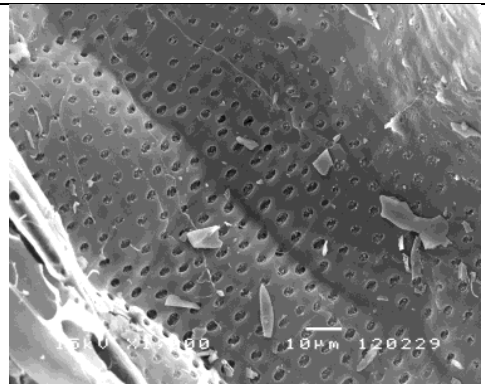

AC, $400{ }^{\circ} \mathrm{C}, 2$ hours

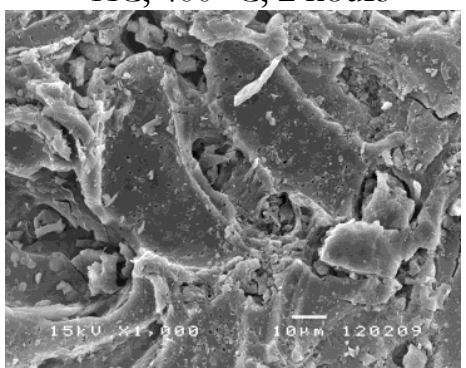

CS, $400 \circ$ C, 2 hours

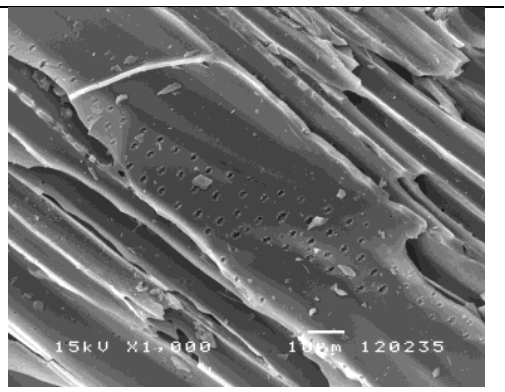

AC, $500{ }^{\circ} \mathrm{C}, 2$ hours

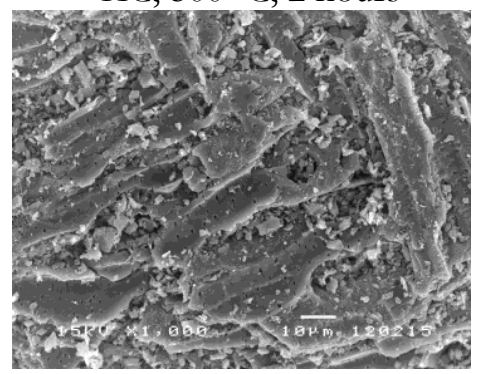

$\mathrm{CS}, 500{ }^{\circ} \mathrm{C}, 2$ hours

Fig. 1. Morphological structure of biochar analyzed by SEM on the prepared Acacia wood (AC) and coconut shell (CS) at 300,400 and $500{ }^{\circ} \mathrm{C}$ with 2 pyrolysis times. 


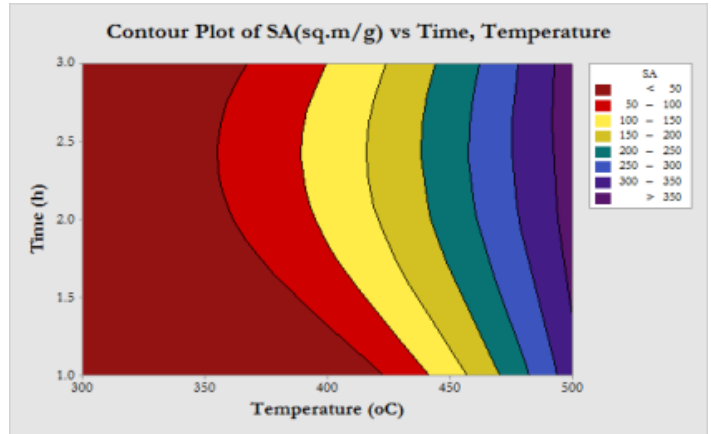

Fig. 2. (a)

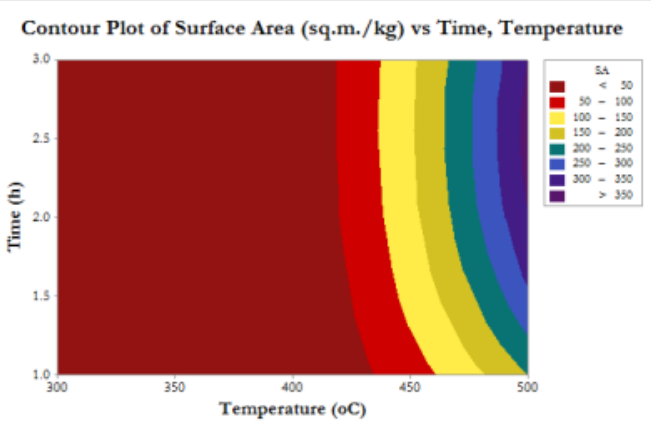

Fig. 2 (b)

Fig. 2. Surface area(SA) of biochar prepared under various conditions (a) Acacia wood (b) coconut shell.

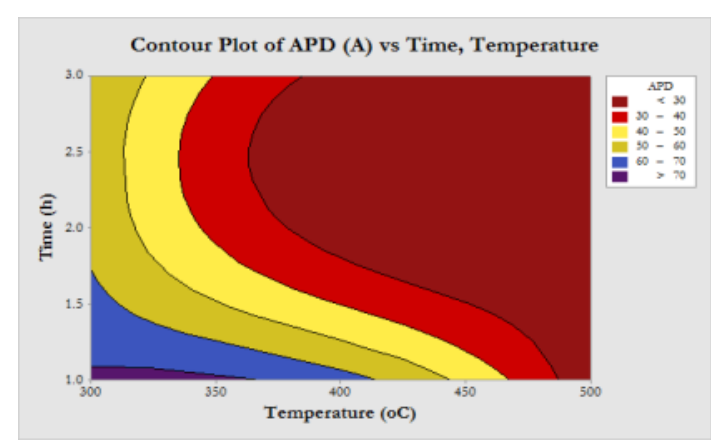

Fig. 3. (a)

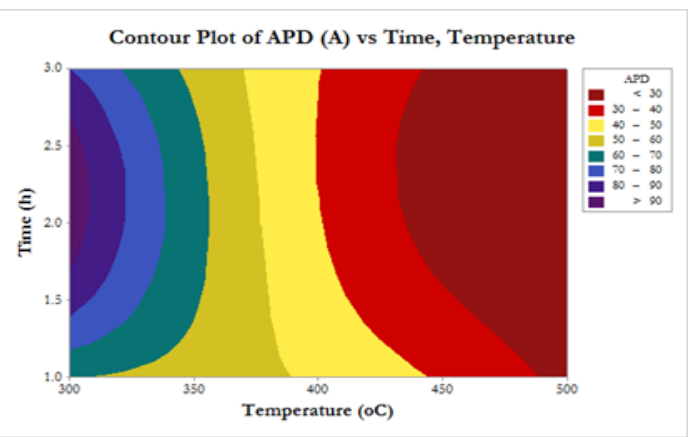

Fig. 3 (b)

Fig. 3. Average Pore Diameter (APD) of biochar prepared under various conditions (a) Acacia wood (b) coconut shell.

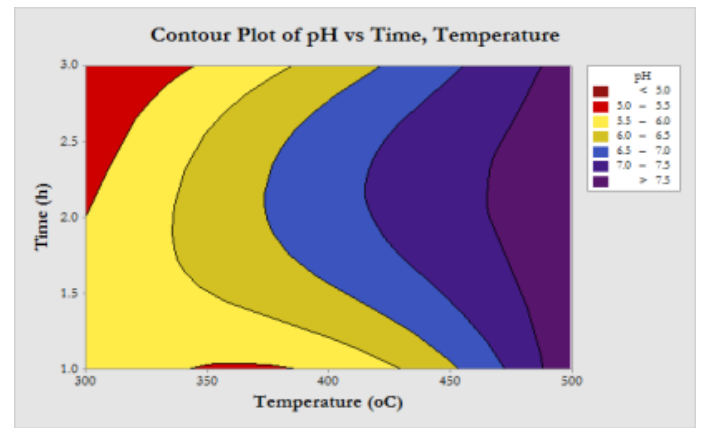

Fig. 4. (a)

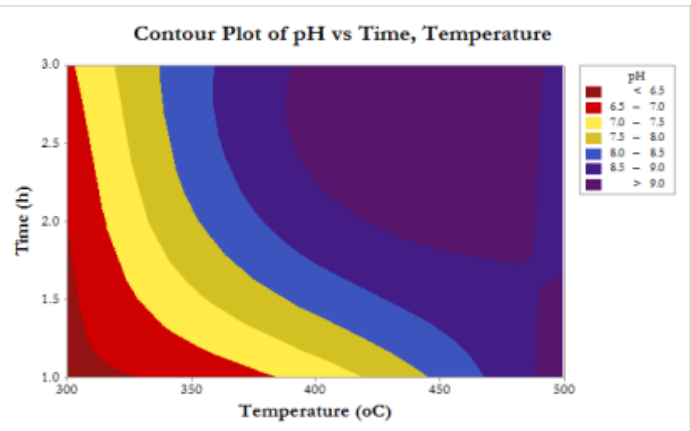

Fig. 4. (b)

Fig. 4. $\mathrm{pH}$ values of biochar prepared under various conditions (a) Acacia wood (b) coconut shell.

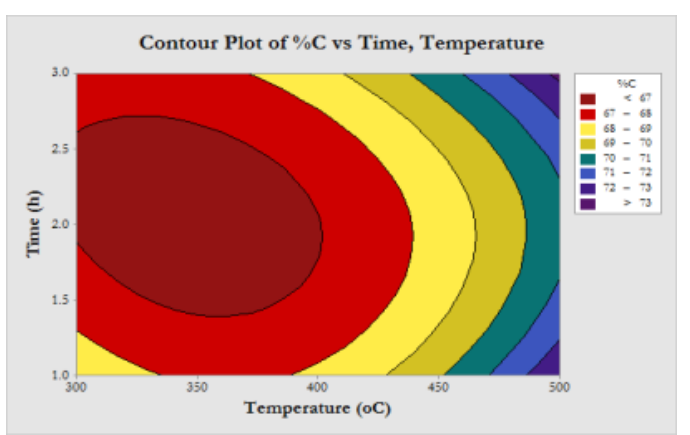

Fig. 5. (a)

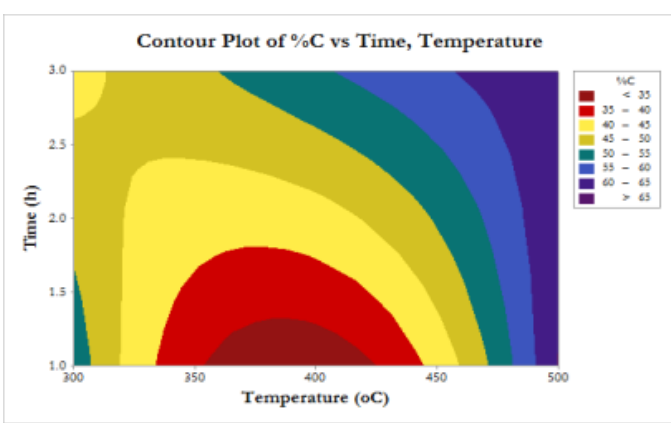

Fig. 5. (b)

Fig. 5. Carbon content of biochar prepared under various conditions (a) Acacia wood (b) coconut shell. 


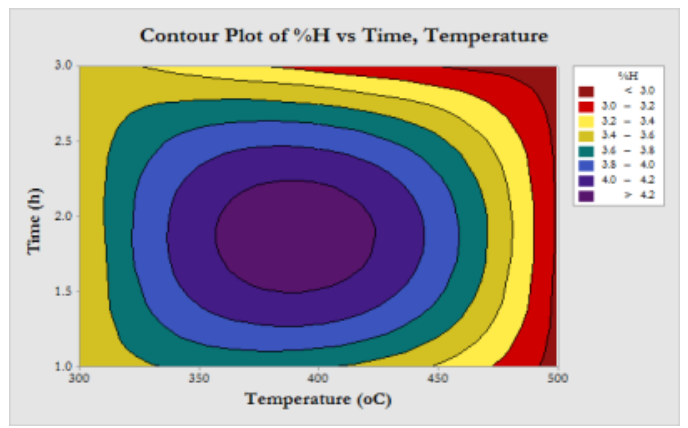

Fig. 6. (a)

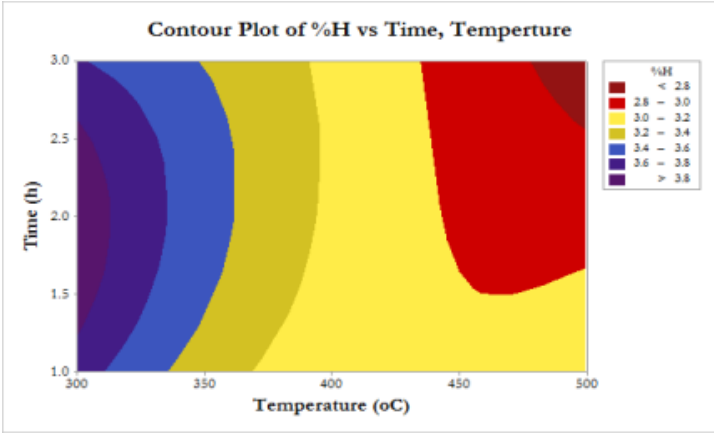

Fig. 6. (b)

Fig. 6. Hydrogen content of biochar prepared under various conditions (a) Acacia wood (b) coconut shell.

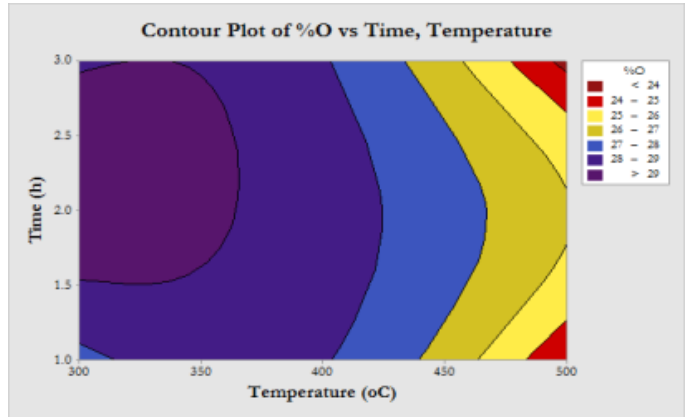

Fig. 7 (a)

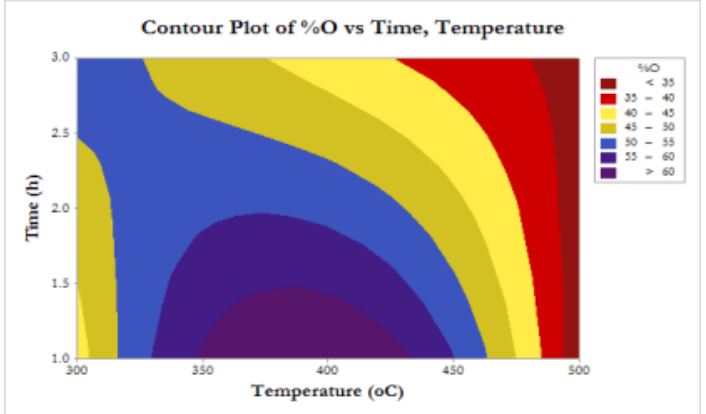

Fig. 7. (b)

Fig. 7. Oxygen content of biochar prepared under various conditions (a) Acacia wood (b) coconut shell.

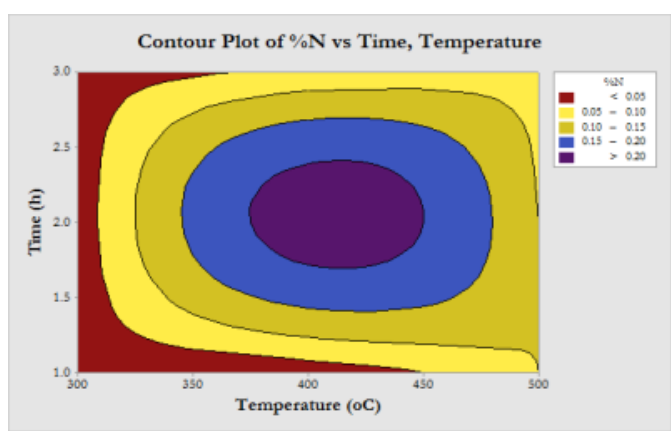

Fig. 8. (a)

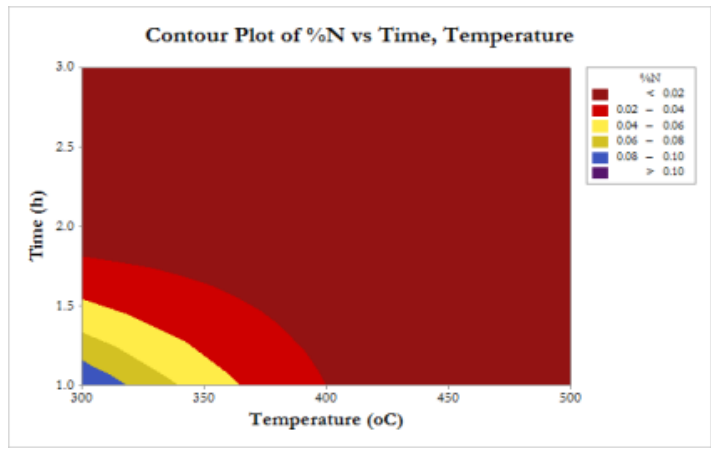

Fig. 8. (b)

Fig. 8. Nitrogen content of biochar prepared under various conditions (a) Acacia wood (b) coconut shell.

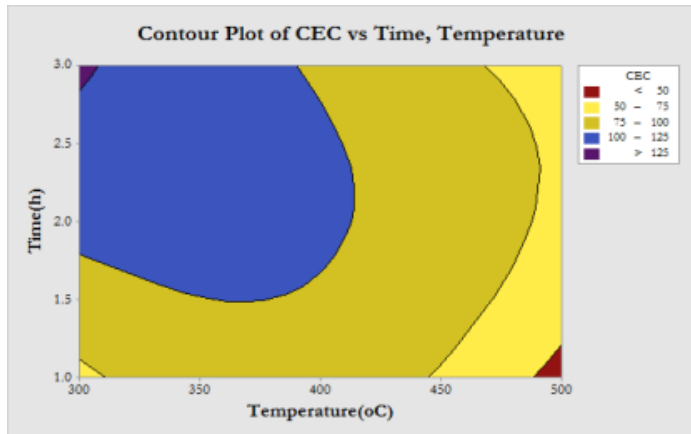

Fig. 9. (a)

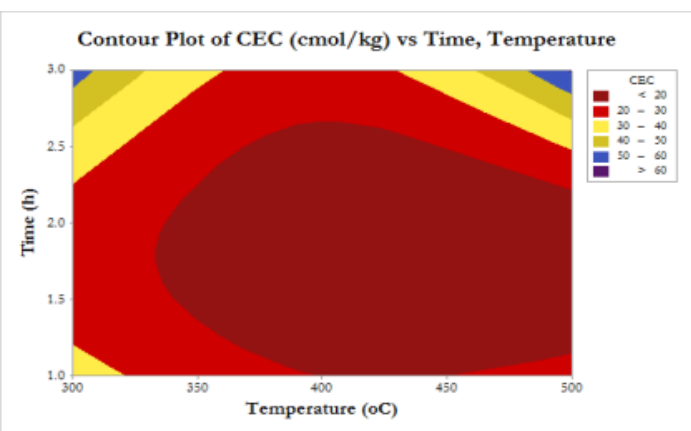

Fig. 9. (b)

Fig. 9. CEC of biochar prepared under various conditions (a) Acacia wood (b) coconut shell. 


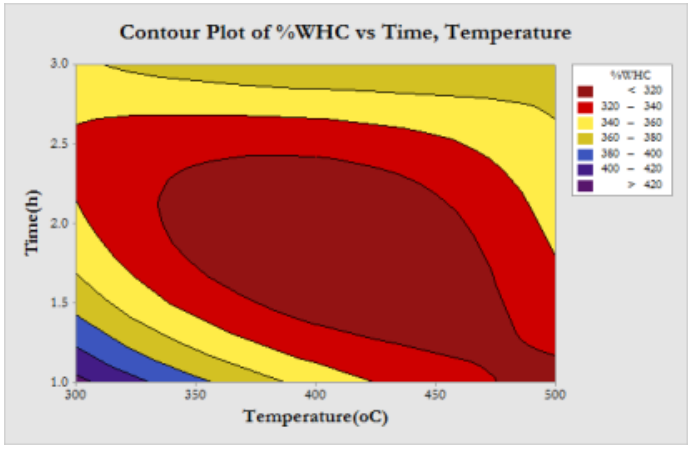

Fig. 10. (a)

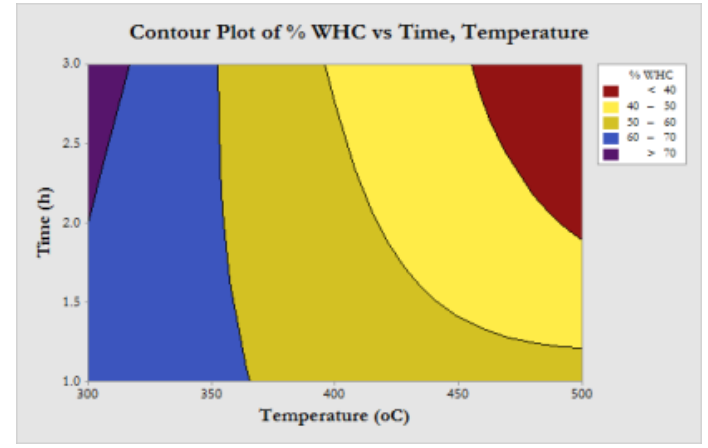

Fig. 10. (b)

Fig. 10. Water Holding Capacity (WHC) of biochar prepared under various conditions: (a) Acacia wood; (b) coconut shell.

\subsection{Comparison of Properties of Biochar Prepared from Acacia Wood and Coconut Shell}

\subsubsection{Surface area (SA)}

The surface area generally found related to nutrient bioavailability. The surface area of biochar is the key indicator of sorption ability of biochar [26]. The biochars can have a large range of surface area depending on the initial biomass and pyrolysis conditions. In soil with low bioavailable $\mathrm{N}$ and $\mathrm{P}$ concentrations sandy soil texture that was biochar amendment, the high surface area, as a consequent of biochar-induced changes in soil physico-chemical properties and biological processes [38] depends on the site-specific conditions. For instance, the surface areas of biochar prepared from corn cob at $250-500^{\circ} \mathrm{C}$ range from $1.86-30.57$ $\mathrm{m}^{2} / \mathrm{g}$ [26] and pine biochar range from $<10-400 \mathrm{~m}^{2} / \mathrm{g}$ [39]. While the surface area of sandy soil is 0.01 $\mathrm{m}^{2} / \mathrm{g}$ approximately, therefore the high surface area biochars can increase the overall surface area of sandy soil. According to the surface area values of the two experimental materials, those values obviously showed big range of difference. Hence, the comparison of surface areas of Acacia wood biochar and coconut shell biochar prepared under nine conditions was revealed by using the paired $\mathrm{T}$-test and found the significant difference at $95 \%$ confident interval $(\mathrm{P}<0.05)$. The results of paired $\mathrm{T}$-test of surface areas of Acacia wood biochar and coconut shell biochar showed that the mean of surface area of Acacia wood biochar was significantly higher than those of coconut shell biochar which indicated the suitability for applying as sandy soil improvement. Both initial biomaterials, Acacia wood biochar $\left(370.37 \mathrm{~m}^{2} / \mathrm{g}\right)$ and coconut shell biochar $\left(347.96 \mathrm{~m}^{2} / \mathrm{g}\right.$ ) showed that the suitable temperature was $500{ }^{\circ} \mathrm{C}$ for 2 hours (Table 2).

Table 2. Results of paired T-test at 95\% confident interval of surface areas of Acacia wood (AC) biochar and coconut shell (CS) biochar.

\begin{tabular}{cccccccc}
\hline & & \multicolumn{3}{c}{ Acacia Wood } & \multicolumn{3}{c}{ Coconut Shell } \\
\cline { 3 - 8 } Temperature & Time & SA & Mean & SD & SA & Mean & SD \\
$\mathbf{h}$ & $\begin{array}{c}\mathbf{m}^{2} / \mathbf{g} \\
\mathbf{m}^{2} \mathbf{g}\end{array}$ & & & & \\
\hline 300 & 1 & 2.14 & & & 1.03 & & \\
300 & 2 & 4.09 & 4.11 & \pm 1.98 & 1.03 & 1.00 & \pm 0.05 \\
300 & 3 & 6.09 & & & 0.95 & & \\
\hline 400 & 1 & 4.56 & & & 4.01 & & \\
400 & 2 & 10.06 & 8.50 & \pm 3.44 & 8.76 & 8.03 & \pm 3.71 \\
400 & 3 & 10.89 & & & 11.32 & & \\
\hline 500 & 1 & 330.63 & & & 199.38 & & \\
500 & 2 & 370.37 & 359.17 & \pm 24.91 & 347.96 & 299.76 & \pm 86.96 \\
500 & 3 & 376.51 & & & 351.95 & & \\
\hline
\end{tabular}

3.2.2. Average pore diameter (APD)

The pore structure is a function of the properties of the original biomass, as well as the process conditions [40]. The higher APD benefits the adsorption of plant nutrients [18]. The varied pyrolysis conditions with 
200 to $500{ }^{\circ} \mathrm{C}$ increased $\mathrm{APD}$ and SA which was appropriate for soil improvement [41]. The $17.46 \pm$ $0.02 \%$ of the biochar APD were reported effectively uninhabitable for most microbes, being with $<1 \mu \mathrm{m}$ in diameter [42]. However, the highly porous structure of biochar helped improve soil water retention [43] though did not necessarily improve available water capacity [43-45]. The comparison of APD of the Acacia wood and coconut shell biochar prepared under nine conditions and using the paired T-test showed an insignificant difference at 95\% confident interval $(\mathrm{P}>0.05)$. Table 3 presents the results of the paired $\mathrm{T}$-test of APD of Acacia wood and coconut shell biochars.

Table 3. Results of paired T-test at 95\% confident interval of APD of Acacia wood (AC) biochar and coconut shell (CS) biochar.

\begin{tabular}{ccccccc}
\hline Variables & $\begin{array}{c}\text { Temperature } \\
\left({ }^{\circ} \mathbf{C}\right)\end{array}$ & Mean & SD & $\begin{array}{c}\text { SE } \\
\text { Mean }\end{array}$ & $\begin{array}{c}\text { T- } \\
\text { value }\end{array}$ & $\begin{array}{c}\text { P- } \\
\text { value }\end{array}$ \\
\hline APD of Acacia wood (AC) & 300 & 63.13 & 7.63 & 4.41 & & \\
$(\AA)$ & 400 & 38.70 & 21.70 & 12.5 & & \\
& 500 & 22.78 & 0.34 & 0.19 & -1.26 & 0.243 \\
\multirow{2}{*}{ APD of coconut shell (CS) } & 300 & 68.60 & 17.40 & 10.00 & & \\
$(\AA)$ & 400 & 43.03 & 4.49 & 2.59 & & \\
\hline Difference & 500 & 23.78 & 2.85 & 1.65 & & - \\
\hline
\end{tabular}

\subsubsection{Water holding capacity (WHC)}

For the sandy soil improvement, the biochar amendment showed tendency of an increase in soil water content and significantly improve the available water capacity depending on soil textures [46]. For the study the water holding capacity of biochar depends on carbon component of wood fibre. The biochar with high WHC amended in sandy loam soil increases water-holding capacity and might lead to the increase in water available for crop use [47] in a certain site. The biochar application on a sloping farmland soil in China increased the WHC of soil, but accelerated organic carbon leaching from the land [48]. Moreover, effects of biochar application on different soil types showed the biochar potential for enhancing crop productivity in coarse sandy soils by increasing soil water retention and improving root development [49]. When compare the WHC of biochar produced from the two plants, AC and CS, the WHC of AC was significantly higher than those of $\mathrm{CS}$ at $95 \%$ of confidential of interval $(\mathrm{P}>0.05)$ by using the paired T-test. (Table 4$)$.

Table 4. Results of paired T-test at 95\% confident interval of WHC of Acacia wood (AC) and coconut shell (CS).

\begin{tabular}{|c|c|c|c|c|c|c|}
\hline Variables & $\begin{array}{l}\text { Temperature } \\
\left({ }^{\circ} \mathrm{C}\right)\end{array}$ & Mean & SD & $\begin{array}{c}\text { SE } \\
\text { Mean }\end{array}$ & $\begin{array}{c}\text { T- } \\
\text { value }\end{array}$ & $\begin{array}{c}\mathrm{P}- \\
\text { value }\end{array}$ \\
\hline \multirow{3}{*}{$\begin{array}{c}\text { WHC of Acacia wood (AC) } \\
(\%)\end{array}$} & 300 & 375.23 & 44.46 & 2.40 & \multirow{6}{*}{13.35} & \multirow{6}{*}{0.000} \\
\hline & 400 & 345.37 & 38.96 & 2.56 & & \\
\hline & 500 & 341.70 & 26.17 & 7.57 & & \\
\hline \multirow{3}{*}{$\begin{array}{c}\text { WHC of Coconut Shell (CS) } \\
(\%)\end{array}$} & 300 & 71.70 & 3.12 & 33.98 & & \\
\hline & 400 & 52.81 & 3.75 & 28.04 & & \\
\hline & 500 & 42.78 & 10.00 & 18.60 & & \\
\hline Difference & & 298.34 & 30.91 & -22.70 & & \\
\hline
\end{tabular}

\subsubsection{Elemental composition}

The comparison of elemental contents of Acacia wood and coconut shell prepared under nine conditions using paired T-test showed that the carbon and oxygen content of biochar from Acacia wood and coconut shell are significantly different at 95\% confident interval $(\mathrm{P}<0.05)$. Meanwhile, the hydrogen and nitrogen content are insignificantly different at 95\% confident interval $(\mathrm{P}>0.05)$ Table 5 to Table 8 presents the results of paired T-test of elemental contents of the Acacia wood and coconut shell biochars. The biomaterial of Acacia wood and coconut shell which composed of $\mathrm{C}, \mathrm{H}, \mathrm{N}$ and $\mathrm{O}$ will be changed by the 
temperatures of pyrolysis [50]. The carbonation in the pyrolytic process, the $\mathrm{C}$ content of the biochar was concentrated while the $\mathrm{H}$ and $\mathrm{O}$ contents both decreased with increasing temperature. This is a typical feedstock response during the pyrolytic process, where the feedstock loses surface functional -OH groups due to dehydration and at higher temperatures loses $\mathrm{C}$-bound $\mathrm{O}$ and $\mathrm{H}$ atoms due to structural core degradation [51]. By the structure degradation, the $\mathrm{H}$ and $\mathrm{O}$ of material were destructed and then causes high APD. The APD relates to $\mathrm{H}$ and $\mathrm{O}$ that accumulated inside the APD and absorbs soil pore water around 1 to 5 Bars in sandy or sandy loam soils [52].

Table 5. Results of paired T-test at 95\% confident interval of carbon content of Acacia wood (AC) and coconut shell (CS).

\begin{tabular}{ccccccc}
\hline Variables & $\begin{array}{c}\text { Temperature } \\
\left({ }^{\circ} \mathbf{C}\right)\end{array}$ & Mean & SD & $\begin{array}{c}\text { SE } \\
\text { Mean }\end{array}$ & $\begin{array}{c}\text { T- } \\
\text { value }\end{array}$ & $\begin{array}{c}\text { P- } \\
\text { value }\end{array}$ \\
\hline \multirow{2}{*}{$\mathrm{C} C$} & 300 & 67.77 & 0.99 & 0.57 & & \\
Acacia wood (AC) & 400 & 67.96 & 0.88 & 0.51 & & \\
& 500 & 72.33 & 1.38 & 0.80 & \multirow{2}{*}{5.32} & 0.001 \\
\multirow{2}{*}{$\% \mathrm{C}$} & 300 & 47.42 & 5.01 & 2.89 & & \\
Coconut Shell (CS) & 400 & 43.07 & 11.22 & 6.48 & & \\
\hline Difference & 500 & 64.77 & 0.71 & 0.41 & & - \\
\hline
\end{tabular}

Table 6. Results of paired T-test at 95\% confident interval of oxygen content of Acacia wood (AC) and coconut shell (CS).

\begin{tabular}{ccccccc}
\hline Variables & $\begin{array}{c}\text { Temperature } \\
\left({ }^{\circ} \mathbf{C}\right)\end{array}$ & Mean & SD & $\begin{array}{c}\text { SE } \\
\text { Mean }\end{array}$ & $\begin{array}{c}\text { T- } \\
\text { value }\end{array}$ & $\begin{array}{c}\text { P- } \\
\text { value }\end{array}$ \\
\hline \multirow{2}{*}{$\%$ O Acacia wood } & 300 & 28.68 & 0.96 & 0.55 & & \\
(AC) & 400 & 28.21 & 0.22 & 0.13 & & \\
\cline { 1 - 5 }$\%$ Coconut Shell & 500 & 24.57 & 1.31 & 0.76 & -5.27 & 0.001 \\
(CS) & 300 & 47.63 & 5.10 & 2.94 & & \\
\hline Difference & 400 & 53.68 & 11.17 & 6.45 & & \\
\hline
\end{tabular}

Table 7. Results of paired T-test at 95\% confident interval of hydrogen content of Acacia wood (AC) and coconut shell (CS).

\begin{tabular}{|c|c|c|c|c|c|c|}
\hline Variables & $\begin{array}{c}\text { Temperature } \\
\left({ }^{\circ} \mathrm{C}\right)\end{array}$ & Mean & SD & $\begin{array}{c}\text { SE } \\
\text { Mean }\end{array}$ & $\begin{array}{c}\text { T- } \\
\text { value }\end{array}$ & $\begin{array}{c}P \text { - } \\
\text { value }\end{array}$ \\
\hline & 300 & 3.45 & 0.05 & 0.03 & \multirow{6}{*}{0.53} & \multirow{6}{*}{0.608} \\
\hline$\% \mathrm{H}$ & 400 & 3.68 & 0.59 & 0.34 & & \\
\hline Acacia wood (AC) & 500 & 2.94 & 0.04 & 0.022 & & \\
\hline \multirow{3}{*}{$\begin{array}{c}\% \mathrm{H} \\
\text { Coconut Shell (CS) }\end{array}$} & 300 & 3.75 & 0.16 & 0.09 & & \\
\hline & 400 & 3.14 & 0.05 & 0.03 & & \\
\hline & 500 & 2.93 & 0.23 & 0.13 & & \\
\hline Difference & & 0.088 & 0.494 & 0.165 & - & - \\
\hline
\end{tabular}


Table 8. Results of paired T-test at 95\% confident interval of nitrogen content of Acacia wood (AC) and coconut shell (CS).

\begin{tabular}{|c|c|c|c|c|c|c|}
\hline Variables & $\begin{array}{c}\text { Temperature } \\
\left({ }^{\circ} \mathrm{C}\right)\end{array}$ & Mean & SD & $\begin{array}{c}\text { SE } \\
\text { Mean }\end{array}$ & $\begin{array}{c}\text { T- } \\
\text { value }\end{array}$ & $\begin{array}{c}\text { P- } \\
\text { value }\end{array}$ \\
\hline \multirow{3}{*}{$\begin{array}{l}\% \mathrm{~N} \text { Acacia wood } \\
(\mathrm{AC})\end{array}$} & 300 & 0.02 & 0.00 & 0.00 & \multirow{6}{*}{1.86} & \multirow{6}{*}{0.099} \\
\hline & 400 & 0.10 & 0.11 & 0.06 & & \\
\hline & 500 & 0.09 & 0.01 & 0.01 & & \\
\hline \multirow{3}{*}{$\begin{array}{c}\% \mathrm{~N} \text { Coconut Shell } \\
\text { (CS) }\end{array}$} & 300 & 0.04 & 0.05 & 0.03 & & \\
\hline & 400 & 0.01 & 0.01 & 0.00 & & \\
\hline & 500 & 0.01 & 0.00 & 0.00 & & \\
\hline Difference & & 0.0500 & 0.0805 & 0.0268 & - & - \\
\hline
\end{tabular}

\subsection{5. $\mathrm{pH}$}

The $\mathrm{pH}$ of the biochars depend on both the content and composition of the mineral fraction, type of initial biomass and conditions under which the amendment is produced [53]. The comparison of the $\mathrm{pH}$ of the biochars from Acacia wood and coconut shell prepared under nine conditions using paired T-test showed a significant difference at 95\% confident interval $(\mathrm{P}<0.05)$. Table 9 presents the results of paired $\mathrm{T}$-test of $\mathrm{pH}$ of the Acacia wood and coconut shell materials. The increase of $\mathrm{pH}$ can be explained by the effects of pyrolysis that cause degradation on different components on the biomaterial. The remain $\mathrm{C}$ in the biochar can be induced more negative charges, so the hydronium ions of water addition were absorbed and caused higher $\mathrm{pH}$. Therefore, the biochar amendment in soil should be control for the $\mathrm{pH}$ change less than one unit $\mathrm{pH}$ [51]. The increase $\mathrm{pH}$ in soil by biochar amendment was also mentioned on the study of surface chemistry variations among a series of laboratory-produced biochars. This study revealed that high temperature biochars will raise soil $\mathrm{pH}$ [54]; although the anion exchange capacity in the biochars was not measured.

Table 9. Results of paired T-test at 95\% confident interval of $\mathrm{pH}$ of Acacia wood (AC) and coconut shell (CS).

\begin{tabular}{|c|c|c|c|c|c|c|}
\hline Variables & $\begin{array}{c}\text { Temperature } \\
\left({ }^{\circ} \mathrm{C}\right)\end{array}$ & Mean & SD & $\begin{array}{c}\text { SE } \\
\text { Mean }\end{array}$ & $\begin{array}{c}\text { T- } \\
\text { value }\end{array}$ & $\begin{array}{c}\text { P- } \\
\text { value }\end{array}$ \\
\hline & 300 & 5.50 & 0.50 & 0.29 & \multirow{6}{*}{-6.29} & \multirow{6}{*}{0.000} \\
\hline $\mathrm{pH}$ & 400 & 6.20 & 0.60 & 0.35 & & \\
\hline Acacia wood (AC) & 500 & 7.80 & 0.10 & 0.06 & & \\
\hline \multirow{3}{*}{$\begin{array}{c}\mathrm{pH} \\
\text { Coconut Shell (CS) }\end{array}$} & 300 & 6.60 & 0.27 & 0.15 & & \\
\hline & 400 & 8.36 & 1.02 & 0.59 & & \\
\hline & 500 & 9.03 & 0.23 & 0.13 & & \\
\hline Difference & & -1.5 & 0.716 & 0.239 & - & - \\
\hline
\end{tabular}

\subsubsection{Cation exchange capacity}

The CEC of soil can be increased by biochar application [25] which can intensify the nutrient uptake ability of the plant. The improving of cation exchange capacity (CEC) and the water holding capacity (WHC) results in the fertility of loamy sand soil. From the soil quality of Center, the strong positive correlations also exist among soil WHC with CEC and biochar micropore area [55]. This was supported by the study of biochar produced from the microwave-assisted catalytic pyrolysis and it showed biochar with high sorption affinity and high CEC which remain essential nutrients for the growth of biomass and food crops [37]. The CEC of soil amended with biochar can be increased up to $20 \%$ [51]. This study shows that the lower temperature presented higher CEC in both biomaterial, therefore to obtained high CEC of biochar, the lower temperature biochars will be better used to increase soil CEC [54]. 
Table 10. Results of paired T-test at 95\% confident interval of the CEC of Acacia wood (AC) biochar and coconut shell (CS) biochar.

\begin{tabular}{ccccccc}
\hline Variables & $\begin{array}{c}\text { Temperature } \\
\left({ }^{\circ} \mathbf{C}\right)\end{array}$ & Mean & SD & $\begin{array}{c}\text { SE } \\
\text { Mean }\end{array}$ & $\begin{array}{c}\text { T- } \\
\text { value }\end{array}$ & $\begin{array}{c}\text { P- } \\
\text { value }\end{array}$ \\
\hline \multirow{2}{*}{ CEC $(\mathrm{cmol} / \mathrm{kg})$} & 300 & 101.2 & 29.10 & 16.80 & & \\
Acacia wood $(\mathrm{AC})$ & 400 & 95.74 & 7.46 & 4.31 & & \\
\cline { 1 - 5 } CEC $(\mathrm{cmol} / \mathrm{kg})$ & 500 & 58.32 & 14.94 & 8.63 & & \\
Coconut Shell $(\mathrm{CS})$ & 300 & 38.70 & 14.82 & 8.56 & & 0.001 \\
& 400 & 19.98 & 6.34 & 3.66 & & \\
\hline Difference & 500 & 33.60 & 24.40 & 14.10 & & \\
\hline
\end{tabular}

\section{Conclusion}

Types of the original biomass and the conditions of preparation process have an impact on the physical and chemical properties of biochar. Results of study revealed that the different types of biomass; Acacia wood and coconut shell, showed a significant effect on the surface area, carbon and oxygen content, $\mathrm{pH}, \mathrm{CEC}$ and WHC of the prepared biochars at a 95\% confident interval. The properties of both biochar reveal optimal condition at $500{ }^{\circ} \mathrm{C}$ at 2 hours of pyrolysis time. The Acacia wood biochar was more suitable than coconut shell biochar when applied as an amendment to degraded-sandy soils due to its higher surface area, greater CEC, and nearly neutral pH. Meanwhile, sandy soil amended with Acacia wood biochar is more appropriate when applied to the typical sandy clay loam soil required organic composts addition together with chemical fertilizer (N:P:K = 15:15:15). The biochar will absorb the ammonium and nitrate for the plant growth in particularly the seeds, but not the shoot and leaves. Therefore, the sandy soil amended with biochar and sources of soil nutrients should be adjusted based on the specificity of site and plant species.

\section{Acknowledgements}

This research was funded by the $90^{\text {th }}$ Anniversary of Chulalongkorn University fund (Ratchadaphiseksomphot Endowment Fund). The equipment for the experiment was provided by the Environmental Research Institute of Chulalongkorn University, The Petroleum and Petrochemical College, Inter-department of Environmental Science and Department of Environmental Science, Faculty of Science, Chulalongkorn University. The raw biomaterials were prepared at Huay Sai Royal Development Study Center.

\section{References}

[1] The Organisation for Economic Co-operation and Development (OECD), Glossary of Environment Statistics, Studies in Methods, Series F, No. 67. United Nations, 1997.

[2] P. Peerapong and B. Limmeechokchai, "Waste to electricity generation in Thailand: Technology, policy, generation cost, and incentives of investment," Engineering Journal, vol. 20, no. 4, pp. 171-177, 2016.

[3] J. F. Parr, R. I. Papendick, and D. Colacicco, "Recycling of organic wastes for a sustainable agriculture," Biological Agriculture \& Horticulture, vol. 3, no. 2-3, pp. 115-130, 1986.

[4] M. Chang and W. Huang, "Production of silicon carbide liquid fertilizer by hydrothermal carbonization processes from silicon containing agricultural waste biomass," Engineering Journal, vol. 20, no. 4, pp. 11-17, 2016.

[5] X. Zhu-Barker, T. A. Doane, and W. R. Horwath, "Role of green waste compost in the production of $\mathrm{N}_{2} \mathrm{O}$ from agricultural soils," Soil Biology and Biochemistry, vol. 83, pp. 57-65, 2015.

[6] K. Komnitsas and D. Zaharaki, "Assessment of human and ecosystem risk due to agricultural waste compost application on soils: A review," Environmental Forensics, vol. 15, no. 4, pp. 312-328. 2014.

[7] P. F. Rizzo, V. Della Torre, N. I. Riera, D. Crespo, R. Barrena, and A. Sánchez, "Co-composting of poultry manure with other agricultural wastes: Process performance and compost horticultural use," Journal of Material Cycles and Waste Management, vol. 17, no. 1, pp. 42-50, 2015. 
[8] D. Killi, R. Anlauf, Y. Kavdir, and M. Haworth, "Assessing the impact of agro-industrial olive wastes in soil water retention: Implications for remediation of degraded soils and water availability for plant growth," International Biodeterioration \& Biodegradation, vol. 94, pp. 48-56, 2014.

[9] M. Hagner, R. Kemppainen, L. Jauhiainen, K. Tiilikkala, and H. Setälä, "The effects of birch (Betula spp.) biochar and pyrolysis temperature on soil properties and plant growth," Soil and Tillage Research, vol. 163, pp. 224-234, 2016.

[10] R. Xu, L. Ferrante, K. Hall, C. Briens, and F. Berruti, "Thermal self-sustainability of biochar production by pyrolysis," Journal of Analytical and Applied Pyrolysis, vol. 91, no. 1, pp. 55-66, 2011.

[11] J. Lehmann and S. Joseph, Biochar for Environmental Management: Science, Technology and Implementation. Routledge, 2015.

[12] J. Lehmann, J. Gaunt, and M. Rondon, "Bio-char sequestration in terrestrial ecosystems-A review," Mitigation and Adaptation Strategies for Global Change, vol. 11, no. 2, pp. 395-419, 2006.

[13] C. Monfreda, N. Ramankutty, and T. W. Hertel, "Global agricultural land use data for climate change analysis," Economic Analysis of Land Use in Global Climate Change Policy, vol. 14, p. 33, 2009.

[14] M. A. Sukiran, L. S. Kheang, N. A. Bakar, and C. Y. May, "Production and characterization of biochar from the pyrolysis of empty fruit bunches," American Journal of Applied Sciences, vol. 8, no. 10, pp. 984, 2011.

[15] S. T. Shafie, M. A. Salleh,, L. L. Hang, M. Rahman, and W. A. W. A. K. Ghani, "Effect of pyrolysis temperature on the biochar nutrient and water retention capacity," Journal of Purity, Utility Reaction and Environment, vol. 1, no. 6, pp. 293-307, 2012.

[16] E. Lopez-Capel, K. Zwart, S. Shackley, R. Postma, J. Stenstrom, D. Rasse, A. Budai, and B. Glaser, "Biochar properties," in Biochar in European Soils and Agriculture: Science and Practice, S. Shackley, G. Ruysschaert, K. Zwart, B. Glaser, Eds. Routledge, 2016, p. 41.

[17] L. G. Godfrey, Hemingway's Geographies: Intimacy, Materiality, and Memory. Palgrave Macmillan, 2016, p. 179.

[18] M. Sika and A. Hardie, "Effect of pine wood biochar on ammonium nitrate leaching and availability in a South African sandy soil," European Journal of Soil Science, vol. 65, no. 1, pp. 113-119, 2014.

[19] N. Borchard, B. Ladd, S. Eschemann, D. Hegenberg, B. M. Möseler, and W. Amelung, "Black carbon and soil properties at historical charcoal production sites in Germany," Geoderma, vol. 232-234, pp. 236-242, 2014.

[20] B. Omil, V. Piñeiro, and A. Merino, "Soil and tree responses to the application of wood ash containing charcoal in two soils with contrasting properties," Forest Ecology and Management, vol. 295, pp. 199-212, 2013.

[21] J. Heitkötter and B. Marschner, "Interactive effects of biochar ageing in soils related to feedstock, pyrolysis temperature, and historic charcoal production," Geoderma, vol. 245-246, pp. 56-64, 2015.

[22] C. W. Edmunds, The Effect of Biochar Amendment to Soil on Bioenergy Crop Yield and Biomass Compostion. University of Tennessee, 2012.

[23] S. D. Joseph, M. Camps-Arbestain, Y. Lin, P. Munroe, C. H. Chia, J. Hook, L. Van Zwieten, S. Kimber, A. Cowie, B. P. Singh, and J. Lehmann, "An investigation into the reactions of biochar in soil," Soil Research, vol. 48, no. 7, pp. 501-515, 2010.

[24] L. Van Zwieten, S. Kimber, A. Downie, S. Morris, S. Petty, J. Rust, and K. Y. Chan, "A glasshouse study on the interaction of low mineral ash biochar with nitrogen in sandy soil," Australian Journal of Soil Research, vol. 48, pp. 569-576, 2010.

[25] K. Y. Chan, L. Van Zwieten, I. Meszaros, A. Downie, and S. Joseph, "Using poultry litter biochars as soil amendments," Soil Research, vol. 46, no. 5, pp. 437-444, 2008.

[26] W. Zheng, B. Sharma, and N. Rajagopalan, "Using biochar as a soil amendment for sustainable agriculture," Illinois Sustainable Technology Center, University of Illinois at Urbana-Champaign, 2010.

[27] K. Jindo, H. Mizumoto, Y. Sawada, and T. Sonoki, "Physical and Chemical characterization of biochars derived from different agricultural residues,” Biogeosciences, vol. 11, pp. 6613-6621, 2014.

[28] J. W. Gaskin, C. Steiner, K. Harris, K. C. Das, and B. Bibens, "Effect of low-temperature pyrolysis conditions on biochar for agricultural use, Trans. Asabe, vol. 51, no. 6, pp. 2061-2069, 2008.

[29] S. Thavivongse, "Testing biomass features of biochar from wood chips before stabilizing," presented at Conference Resource Management and Improving the Quality of Life Works, 2011.

[30] M. Yamato, Y. Okimori, I. F. Wibowo, S. Anshori, and M. Ogawa, "Effects of the application of charred bark of Acacia mangium on the yield of maize, cowpea and peanut, and soil chemical 
properties in South Sumatra, Indonesia," Soil Science and Plant Nutrition, vol. 52, no. 4, pp. 489-495, 2006.

[31] J. Novak, G. Sigua, D. Watts, K. Cantrell, P. Shumaker, A. Szogi, M. G. Johnson, and K. Spokas, "Biochars impact on water infiltration and water quality through a compacted subsoil layer," Chemosphere, vol. 142, pp. 160-167, 2016.

[32] S. Wijitkosum and W. Kallayasiri, "The use of Biochar to increase productivity of indigenous upland rice (Oryzasativa L.) and improve soil properties," Research Journal of Pharmaceutical, Biological and Chemical Sciences, vol. 6, no. 2, pp. 1326-1336, 2015.

[33] International Biochar Initiative, Standardized Product Definition and Product Testing Guidelines for Biochar that Is Used in Soil, IBI biochar standards, 2016.

[34] H. D. Chapman, "Cation-exchange capacity," in Methods of Soil Analysis_Chemical and Microbiological Properties, C. A. Black, Ed. American Society of Agronomy, 1965, pp. 891-901.

[35] J. W. Tukey, "Comparing individual means in the analysis of variance," Biometrics, vol. 5, no. 2, pp. 99114,1949

[36] J. S. McDonald-Wharry, M. Manley-Harris, and K. L. Pickering, "Reviewing, combining, and updating the models for the nanostructure of non-graphitizing carbons produced from oxygen-containing precursors," Energy \& Fuels, vol. 30, no. 10, pp. 7811-7826, 2016.

[37] B. A. Mohamed, N. Ellis, C. S. Kim, X. Bi, and A. E. R. Emam, "Engineered biochar from microwave-assisted catalytic pyrolysis of switchgrass for increasing water-holding capacity and fertility of sandy soil," Science of the Total Environment, vol. 566-567, pp. 387-397, 2016.

[38] S. Gul and J. K. Whalen, "Review paper: Biochemical cycling of nitrogen and phosphorus in biocharamended soils," Soil Biology and Biochemistry, vol. 103, pp. 1-15, 2016.

[39] C. E. Brewer, K. Schmidt-Rohr, J. A. Satrio, and R. C. Brown, "Characterization of biochar fron fast pyrolysis and gasification systems," Environmental Progress \& Sustainable Energy, vol. 28, pp. 389-396, 2009.

[40] M. Keiluweit, P. S. Nico, M. G. Johnson, and M. Kleber, "Dynamic molecular structure of plant biomass-derived black carbon (biochar)," Environmental Science \& Technology, vol. 44, pp. 4693-4703, 2010 .

[41] Institute for Environment and Sustainability in the European Commission Joint Research Centre. (2010). ILCD Handbook. [Online]. Available: http://eplca.jrc.ec.europa.eu

[42] R. S. Quilliam, H. C. Glanville, S. C. Wade, and D. L. Jones, "Life in the 'charosphere'-Does biochar in agricultural soil provide a significant habitat for microorganisms?," Soil Biology and Biochemistry, vol. 65, pp. 287-293, 2013.

[43] R. C. Devereux, C. J. Sturrock, and S. J. Mooney, "The effects of biochar on soil physical properties and winter wheat growth, Earth and Environ. Sci., vol. 103, no. 1, pp. 13-18, 2012.

[44] R. T. Barnes, M. E. Gallagher, C. A. Masiello, Z. Liu, and B. Dugan, "Biochar-induced changes in soil hydraulic conductivity and dissolved nutrient fluxes constrained by laboratory experiments," PLoS One, vol. 9, no. 9, pp. e108340, 2014.

[45] H. M. S. K. Herath, M. Camps-Arbestain, and M. Hedley, "Effect of biochar on soil physical properties in two contrasting soils: An Alfisol and an Andisol," Geoderma, vol. 209-210, pp. 188-197, 2013.

[46] S. Abel, A. Peters, S. Trinks, H. Schonsky, M. Facklam, and G. Wessolek, "Impact of biochar and hydrochar addition on water retention and water repellency of sandy soil," Geoderma, vol. 202-203, pp. 183-191, 2013.

[47] A. S. Basso, F. E. Miguez, D. A. Laird, R. Horton, and M. Westgate, "Assessing potential of biochar for increasing water-holding capacity of sandy soils," Gcb Bioenergy, vol. 5, no. 2, pp. 132-143, 2013.

[48] C. Liu, H. Wang, X. Tang, Z. Guan, B. J. Reid, A. U. Rajapaksha, Y. S. Ok, and H. Sun, "Biochar increased water holding capacity but accelerated organic carbon leaching from a sloping farmland soil in China," Environmental Science and Pollution Research, vol. 23, no. 2, pp. 995-1006, 2016.

[49] V. Hansen, H. Hauggaard-Nielsen, C. T. Petersen, T. N. Mikkelsen, and D. Müller-Stöver, "Effects of gasification biochar on plant-available water capacity and plant growth in two contrasting soil types," Soil and Tillage Research, vol. 161, pp. 1-9, 2016.

[50] J. M. Novak, W. J. Busscher, D. L. Laird, M. Ahmedna, D. W. Watts, and M. A. Niandou, "Impact of biochar amendment on fertility of a southeastern coastal plain soil," Soil Science, vol. 174, no. 2, pp. 105-112, 2009. 
[51] M. J. Antal and M. Grønli, "The art, science, and technology of charcoal production,” Industrial \& Engineering Chemistry Research, vol. 42, no. 8, pp. 1619-1640, 2003.

[52] D. A. Laird, P. Fleming, D. D. Davis, R. Horton, B. Wang, and D. L. Karlen, "Impact of biochar amendments on the quality of a typical Midwestern agricultural soil," Geoderma, vol. 158, no. 3, pp. 443-449, 2010.

[53] B. Singh, B. P. Singh, and A. L. Cowie, "Characterisation and evaluation of biochars for their application as a soil amendment," Soil Research, vol. 48, no. 7, pp. 516-525, 2010.

[54] A. Mukherjee, A. Zimmerman, and W. Harris, "Surface chemistry variations among a series of laboratory-produced biochars," Geoderma, vol. 163, no. 3, pp. 247-255, 2011.

[55] P. Pinitpon, "Effect of biochar application in sandy soil rain shadow area on sesame (Sesamun indicum L.) production,” Ph.D. thesis, Graduate School, Chulalongkorn University, 2015. 